\title{
Methane capture installation for greenhouse gasses emission reduction in palm oil mill
}

\author{
Deffi Ayu Puspito Sari ${ }^{1}$, Primazahra Agya Zaenal Mutaqin ${ }^{1}$, Pawenary ${ }^{2}$, Edy Herianto Majlan ${ }^{3}$ \\ ${ }^{1}$ Environmental Engineering, Universitas Bakrie, Indonesia \\ ${ }^{2}$ Sekolah Tinggi Teknik PLN, Indonesia \\ ${ }^{3}$ Fuel Cell Institute, University Kebangsaan Malaysia, Malaysia
}

\begin{abstract}
The palm oil industry produces greenhouse gas emissions such as carbon dioxide $\left(\mathrm{CO}_{2}\right)$, methane $\left(\mathrm{CH}_{4}\right)$, nitrous oxide $\left(\mathrm{N}_{2} \mathrm{O}\right)$ and other gases through the processing, transportation of vehicles and waste produced. Greenhouse gas emissions can be calculated by the Intergovernmental Panel On Climate Change (IPCC) method. The biggest emission source in the palm oil mill (POM) industry comes from Palm Oil Mill Effluent (POME) and can be reduced by capturing the methane. By making an estimation of greenhouse gases (GHGs) from the operation of the methane capture installation, the total emissions reduced that produced will be known. The palm oil mills that analyzed was a palm oil mill located in Belitung Island, Indonesia. The purpose of this study was to estimate the GHGs emission reduction from the palm oil mill after the installation of biogas methane capture facility. Using IPCC method, the total actual emissions reduction is $70,6 \%$, and without addition of sludge removal in the reactor, the reduction is $84,7 \%$.
\end{abstract}

Keywords: Greenhouse gas emissions, POME, methane capture installation, palm oil industry, IPCC

\section{Introduction}

The current global supply of palm oil comes from Indonesia, and 95\% of the land used for plantation is in Sumatera and Kalimantan. According to the Directorate General of Plantations, the Ministry of Agriculture and the Indonesian Palm Oil Association (GAPKI), Indonesia palm oil production has reached 43.9 million metric tons (MMT) in 2018 [1]. When combined with Malaysia, 85\% of the world's palm oil comes from both [2]. With this amount, the waste generated from the palm oil industry will also be directly proportional. The wastewater produced in Palm Oil Mill, which is Palm Oil Mill Effluent (POME), contains organic material which, with the microbial activity, will produce methane and carbon dioxide [3].

Without serious treatment, environmental degradation will occur. The high organic content of POME has high potential in polluting the environment in terms of high Chemical Oxygen Demand (COD) and produces Greenhouse Gas (GHG) emissions, therefore special handling is needed to keep the palm oil industry sustainable. Appropriate efforts can be made by making methane capture installation [4].

With the installation of methane capture, electrical energy is produced from anaerobic chemical reaction [5] in POME which becomes methane as generator fuel [6]. Moreover, methane produced can be utilized and not released into the atmosphere. The accumulation of methane that has Global Warming Potential (GWP) 28 will play a role in global warming [7]. The electricity generated from the methane capture installation is green energy to reduce the company's emissions from the use of fossil fuels. Industries that use the methane capture installation can sell the electricity produced to produce profit [8]. Furthermore, the emission at the POM will be reduced. Depth studies need to be done for each company that plans to capture the methane because it needs to be adapted to the design and characteristics of each mill. Even though the palm oil mill industry with the methane capture installation does not process all the POME, the company will still reduce the emissions [9]. In term of the emission produced, the largest emitter is generated from wastewater POME [10].

Based on the above context, the author estimated the GHG emission reduction from palm oil mill that installed methane capture facility (biogas reactor or power plant). The IPCC method applied to analyze the GHG reduction. However, due to the lack of available data, Agriculture, Forestry, and Other Land Use (AFOLU) sector do not include in the calculation. Emission Factor (EF) that used in for energy sector calculation is using the default EF and for waste sector by using industry-specific EF. Results of this study can be used as a consideration for the company to build the methane capture installation or compiling the GHG inventory to report the GHG from palm oil industry. 


\section{IPCC Approach}

In order to estimate the GHG of POM, the system boundaries and base year of calculation needed to be fixed. Various data on production of Crude Palm Oil (CPO) and waste generation are needed. Energy consumption from combustion covered in the IPCC method. Biogenic materials that considered as fuel related to process are considered zero. GHGs that IPCC cover are $\mathrm{CO}_{2}, \mathrm{CH}_{4}$, and $\mathrm{N}_{2} \mathrm{O}$ for direct emission. $\mathrm{CH}_{4}$ and $\mathrm{N}_{2} \mathrm{O}$ should be converted into $\mathrm{CO}_{2}$ eq according to their GWP [11]. The newest GWP can be seen in Table 4.

\section{Materials and Methods}

The method used in this study is from IPCC 2006. GHG was estimated at a processing plant that produces CPO. The company owns a processing plant for CPO, Palm Kernel (PK), Palm Kernel Expeller (PKE), and derived product from refining process i.e. palm olein and palm stearin. The GHG generated quantified from 2012 to 2017.

\subsection{Data Collection}

Energy consumption and fuel consumption data were collected from the company's data. When such data to calculation is not available, GHG estimated based on default IPCC 2006. The baseline year chosen is from 2012 to 2017 . The sector to be included in estimation are: 1)energy stationary combustion; 2)energy from mobile combustion; 3)wastewater treatment and discharge. The data source is shown in Table 2.

\subsection{Calculating the GHG}

The net calorific values used to convert the data on fuel consumption from mass units to energy units are provided by the IPCC [12]. The energy sector in POM identified from stationary sources of combustion and mobile sources of combustions. Energy sector calculated by using Tier 1 method of the IPCC [13], with the following equation:

1) Stationary combustion equation

Emission $(\mathrm{kg} /$ year $)=$ Energy consumption $(\mathrm{TJ} / \mathrm{yr}) \times \mathrm{EF}(\mathrm{kg} / \mathrm{TJ})$

Source: [13]

Conversion mass unit energy unit

Energy consumption $(\mathrm{TJ})=$ Energy consumption (mass unit) $\mathrm{x}$ calorific value* $(\mathrm{TJ} / \mathrm{mass}$ unit)

2) Mobile combustion equation

Emission $=\sum$ Fuel $\mathrm{x}$ EF

Where the EF is shown in Table 1.

Table 1 EFs of IPCC

\begin{tabular}{|c|c|c|}
\hline Fuel & Calorific Value* & Sources \\
\hline Diesel Oil & $38 \times 10^{-6} \mathrm{TJ} /$ liter & [14] \\
\hline Fiber & $19,098 \mathrm{KJ} / \mathrm{kg}$ & [15] \\
\hline Shell & $20,108 \mathrm{KJ} / \mathrm{kg}$ & [15] \\
\hline Biogas & $21,5 \mathrm{MJ} / \mathrm{m}^{3}$ & [16] \\
\hline EFB & $16 \mathrm{MJ} / \mathrm{kg}$ & [17] \\
\hline
\end{tabular}

3) The waste sector in POM identified from wastewater treatment and discharge. Energy sector calculated by using Tier 2 method of the IPCC [18] with the industry-specific EF. Wastewater 
treatment is final process in POM and represents the GHG due to microbial activity occurred in POME. The GHG can be estimated by following the equation:

Total organic degradable material in from industrial wastewater [19]

TOWi $=$ Pi $x W i \times C O D i$

where

$\mathrm{Pi}=$ total industrial product for industrial sector ton/yr

$\mathrm{Wi} \quad=$ wastewater generated, $\mathrm{m}^{3} /$ ton product

COD $=$ Chemical oxygen demand (plant-specific),

Emission factor for industrial wastewater

$$
\mathrm{EFj}=\text { Bo } x M C F j
$$

Total emission from industrial wastewater [19]

$$
\text { Emisi } \mathrm{CH} 4=\sum_{i}[(T O W i-S i) \mathrm{EFi}-\mathrm{Ri}]
$$

where

TOW : total organically degradable material in wastewater, $\mathrm{kg} \mathrm{COD} / \mathrm{yr}$

$\mathrm{S} \quad$ : organic component removed as sludge inventory, $\mathrm{kg} \mathrm{COD} / \mathrm{yr}$

i : industrial sector

$\mathrm{R}$ : amount $\mathrm{CH}_{4}$ recovered in inventory year, $\mathrm{kg} \mathrm{CH}_{4} / \mathrm{yr}$

$\mathrm{EFj}$ : emission factor, $\mathrm{kg} \mathrm{CH} / \mathrm{kg} \mathrm{BOD}$

$\mathrm{MCFj}$ : methane correction factor

Bo : maximum $\mathrm{CH}_{4}$ producing capacity, $\mathrm{kg} \mathrm{CH} / 4 \mathrm{~kg} \mathrm{COD}$

\begin{tabular}{|c|c|c|c|c|c|}
\hline Data & $2012-2013$ & 2013-2014 & $2014-2015$ & $2015-2016$ & 2016-2017 \\
\hline \multicolumn{6}{|l|}{ 1A2 Manufacture (biomass) } \\
\hline $\begin{array}{l}\text { Biogas (POME to methcap) } \\
\left(\mathrm{m}^{3}\right)\end{array}$ & 2933431,44 & 7480873,69 & 5974563 & 4799078 & 5974328 \\
\hline Shell $(\mathrm{kg})$ & 24567400 & 26421400 & 26362400 & 22271500 & 22371870 \\
\hline Fibre $(\mathrm{kg})$ & 49134800 & 52842700 & 52724800 & 44543000 & 44743740 \\
\hline \multicolumn{6}{|l|}{ 1A2 Manufacture (liquid) } \\
\hline Solar (genset) (liter) & 709120,4 & 680556 & 428421 & 373618 & 103017 \\
\hline \multicolumn{6}{|l|}{ 1A3 Transport (liquid) } \\
\hline Solar (liter) & 2729712,67 & 2935706,67 & 2929153 & 2474609 & 650122,7 \\
\hline \multicolumn{6}{|l|}{ 4B $\mathrm{CH}_{4}$ Emission } \\
\hline Compost (Gg) & 0 & 0 & 0 & 2,81377 & 12,03141 \\
\hline \multicolumn{6}{|l|}{$4 \mathrm{~B} \mathrm{~N}_{2} \mathrm{O}$ Emission } \\
\hline Compost (Gg) & 0 & 0 & 0 & 2,81377 & 12,03141 \\
\hline \multicolumn{6}{|c|}{ 4D2 TOW Industrial Wastewater } \\
\hline CPO production (ton/year) & 84426,94 & 92546,09 & 94695,11 & 78165,8 & 76004,17 \\
\hline $\begin{array}{l}\text { POME generated }\left(\mathrm{m}^{3} / \text { ton }\right. \\
\text { product })\end{array}$ & 1,842746223 & 2,512161782 & 2,64911639 & 1,943351901 & 2,389251116 \\
\hline $\mathrm{COD}\left(\mathrm{kg} \mathrm{COD} / \mathrm{m}^{3}\right)$ & 53,529 & 70,823 & 71,78 & 94,15932 & 91,6136 \\
\hline \multicolumn{6}{|c|}{ 4D2 $\mathrm{CH}_{4} \mathrm{EF}$ Industrial Wastewater } \\
\hline $\begin{array}{l}\text { Methane producing capacity } \\
(\mathrm{kg} \mathrm{CH} / \mathrm{kg} \mathrm{COD}) \\
\text { 4D2 } \mathrm{CH}_{4} \text { Industrial Wastev }\end{array}$ & 0,220 & 0,166 & 0,164 & 0,125 & 0,128 \\
\hline $\begin{array}{l}\text { Sludge removed (kg } \\
\text { COD/year) }\end{array}$ & 0 & 0 & 0 & 2813770 & 12031400 \\
\hline $\begin{array}{l}\text { Recovered } \mathrm{CH}_{4} \text { in each } \\
\text { industry }\left(\mathrm{kg} \mathrm{CH}_{4} / \text { year }\right)\end{array}$ & 0 & 0 & 0 & 0 & 0 \\
\hline
\end{tabular}

Table 2 Data Collection 


\section{Results and Discussion}

In the wastewater treatment and discharge sector, there are default emission factors, but in this calculation, the emission factors are used using industry-specific. Waste data obtained from the company will be calculated to find its emission factors, by multiplied Bo with Methane Correction Factor (MCF), which each type of treatment has a different value. The value of Bo depends on the waste COD and the amount of $\mathrm{CH} 4$ produced. the higher the COD value, the smaller the Bo value [11]. Details of the value of Bo for all company calculations and time series can be seen in Table 3.

Table 3 Methane Gas Production from POME in POM

\begin{tabular}{|c|c|c|c|c|c|c|}
\hline Period & Treatment & $\begin{array}{c}\text { Volume POME } \\
\text { treated }(\mathrm{m} 3)\end{array}$ & $\mathrm{COD}(\mathrm{kg} / \mathrm{m} 3)$ & COD (kg) & $\begin{array}{l}\text { CH4 Production } \\
\text { (ton) }\end{array}$ & $\begin{array}{c}\text { Bo }(\mathrm{CH} 4 / \mathrm{COD} \\
\text { in } \mathrm{kg})\end{array}$ \\
\hline \multirow[t]{2}{*}{$2012-2013$} & Methcap & 116.192 & 53,53 & 6.219 .627 & 1.367 & 0,22 \\
\hline & Open Lagoon & 86.548 & 53,53 & 4.632 .815 & 2.385 & 0,22 \\
\hline \multirow[t]{2}{*}{ 2013-2014 } & Methcap & 296.315 & 70,82 & 20.985 .946 & 3.486 & 0,17 \\
\hline & Open Lagoon & 6.653 & 70,82 & 471.195 & 3.565 & 0,17 \\
\hline \multirow[t]{2}{*}{ 2014-2015 } & Methcap & 90.253 & 71,78 & 6.478 .379 & 2.784 & 0,16 \\
\hline & Open Lagoon & 236.651 & 71,78 & 16.986 .798 & 3.846 & 0,16 \\
\hline \multirow[t]{2}{*}{ 2015-2016 } & Methcap & 190.090 & 94,16 & 17.898 .764 & 2.237 & 0,12 \\
\hline & Open Lagoon & 7.862 & 94,16 & 740.267 & 2.329 & 0,12 \\
\hline \multirow[t]{2}{*}{ 2016-2017 } & Methcap & 236.642 & 91,61 & 21.679 .585 & 2.784 & 0,13 \\
\hline & Open Lagoon & - & 91,61 & - & 2.784 & 0,13 \\
\hline
\end{tabular}

The emission calculated then need to be converted into $\mathrm{CO}_{2}$ eq. $\mathrm{CH}_{4}$ and $\mathrm{N}_{2} \mathrm{O}$ converted based on their GWP. The following GWP those gases can be seen in Table 4 and the result of GHG emission calculation is shown in Table 5:

Table 4 Global Warming Potential

\begin{tabular}{cc}
\hline Gases & GWP \\
\hline $\mathrm{CO}_{2}$ & 1 \\
$\mathrm{CH}_{4}$ & 28 \\
$\mathrm{~N}_{2} \mathrm{O}$ & 265 \\
\hline \multicolumn{3}{c}{ Source : [7] }
\end{tabular}

Table 5 Total Emission

\begin{tabular}{cccccc}
\hline Keterangan & $2012-2013$ & $2013-2014$ & $2014-2015$ & $2015-2016$ & $2016-2017$ \\
\hline Total Emission $\mathrm{Gg} \mathrm{CO}_{2} \mathrm{e}$ & 32,62 & 12,07 & 33,37 & 10,70 & 4,26 \\
\hline
\end{tabular}

Total emissions tend to decrease from year to year. The greater the POME produced, the greater the emissions, but if the $\mathrm{CH}_{4}$ is capture in methane capture installation (biogas reactor) the emissions are saved. In the 2015-2016 and 2016-2017 periods, the calculation of waste emissions will be reduced by sludge removed. From 2015 to 2016 and 2016-2017 the emission value will decrease due to sludge utilization activities which will affect the amount of Wastewater TOW. The smallest emission value occurred in the period 2016-2017 due to all POME produced was entered into the Biogas Power Plant, so there are no emissions from open ponds (emissions only come from burning fossil fuels). Table 6 shows the percentage reduction of GHG emissions. 
Table 6 Reduction of Emission

\begin{tabular}{ccccccc}
\hline Period & $\begin{array}{c}\text { Energy } \\
\text { emission } \\
(\text { Gg CO2e })\end{array}$ & $\begin{array}{c}\text { Open } \\
\text { Lagoon } \\
\text { Emission } \\
(\text { Gg CO2e })\end{array}$ & $\begin{array}{c}\text { Methane } \\
\text { capture } \\
\text { Emission } \\
(\text { Gg CO2e })\end{array}$ & $\begin{array}{c}\text { Total Waste } \\
\text { Emission } \\
(\text { Gg CO2e })\end{array}$ & $\begin{array}{c}\text { Total } \\
\text { Emission }(G g \\
\text { CO2e })\end{array}$ & $\begin{array}{c}\text { Percentage of } \\
\text { reduction }(\%)\end{array}$ \\
\hline $2012-2013$ & 9,808 & 22,810 & 30,623 & 53,434 & 32,619 & 57,311 \\
$2013-2014$ & 10,316 & 1,753 & 78,097 & 79,850 & 12,070 & 97,804 \\
$2014-2015$ & 9,585 & 23,787 & 62,372 & 86,159 & 33,373 & 72,392 \\
$2015-2016$ & 8,625 & 9,948 & 42,224 & 52,172 & 18,573 & 80,932 \\
$2016-2017$ & 4,263 & 34,613 & 27,756 & 62,369 & 38,875 & 44,504 \\
\hline
\end{tabular}

Table 6 shows the number of emissions from the energy and waste sectors. The company has a sludge removal system starting in the 2015-2016 period. The amount of energy sector emissions is affected by the number of fossil fuels used both in the process and in transportation. The longer the distance between the plantations, the more fuel consumption, and the greater emissions. In this case, POME waste will enter the methane capture installation and the rest will be processed in an open lagoon. The waste emissions mentioned in table 6 come from the emissions of waste discharged into the open lagoon. Methane capture emissions come from emissions produced by methane capture installations, but they do not add up to total emissions because they include biogenic materials to produce energy. Then emissions from open lagoon full are emissions if all waste is processed into an open lagoon. These emissions are calculated to determine the reduction of emissions from the operation of the methane capture installation. The total emissions are the actual value of the total emissions from the energy and waste sector emissions.

The amount of energy emissions based on the use of fossil fuels tends to decrease because the transportation distance is also reduced. Waste emissions tend to fluctuate with large differences. That is because not all POME is processed into methane capture installation. In the period 2015-2016 and 20162017, it did not originate from POME emissions which were processed in the open lagoon, but also from sludge removal as well. Methane capture emissions tend to increase then decrease, the decrease is due to sludge removal. Because in the calculation, the emissions in the methane capture installation will be reduced by the correct amount of sludge removal. Open lagoon full emission is total emissions from waste, but this is not an actual condition. The amount is influenced by the amount of POME produced. The company's actual emissions can be known from the total emission from sectors of energy and waste. The average emission reduction is $70.588 \%$, but to find out the emission reduction from the operation of the methane capture installation it is necessary to eliminate the variable sludge removal (Table 7).

Table 7 Reduction of Emission (without sludge removal)

\begin{tabular}{ccccccc}
\hline Period & $\begin{array}{c}\text { Energy } \\
\text { emission } \\
(\text { Gg CO2e })\end{array}$ & $\begin{array}{c}\text { Open } \\
\text { Lagoon } \\
\text { Emission } \\
(\text { Gg CO2e })\end{array}$ & $\begin{array}{c}\text { Methane } \\
\text { capture } \\
\text { Emission } \\
(\text { Gg CO2e })\end{array}$ & $\begin{array}{c}\text { Total Waste } \\
\text { Emission } \\
(\text { Gg CO2e })\end{array}$ & $\begin{array}{c}\text { Total } \\
\text { Emission }(G g \\
\text { CO2e })\end{array}$ & $\begin{array}{c}\text { Percentage of } \\
\text { reduction }(\%)\end{array}$ \\
\hline $2012-2013$ & A & B & C & $(\mathrm{B}+\mathrm{C})=\mathrm{D}$ & $(\mathrm{A}+\mathrm{B})=\mathrm{E}$ & $(\mathrm{C} / \mathrm{D}) * 100$ \\
$2013-2014$ & 10,316 & 1,753 & 78,097 & 53,434 & 32,619 & 57,311 \\
$2014-2015$ & 9,585 & 23,787 & 62,372 & 86,850 & 12,070 & 97,804 \\
$2015-2016$ & 8,625 & 2,072 & 50,100 & 52,172 & 33,373 & 72,392 \\
$2016-2017$ & 4,263 & - & 62,369 & 62,369 & 4,693 & 96,028 \\
\hline
\end{tabular}

In table 7, a calculation is made if sludge removal is not taken into account to obtain a reduction in emissions only from the methane capture installation. The number of waste emissions in the period 20152016 and 2016-2017 came from POME waste obtained at the open pond only. From 2016 to 2017 the number of emissions is zero because all the POME entered is processed into the methane capture installation entirely. By doing this calculation, it can be known as actual methane capture emissions so that emissions reductions 
can be discovered. The average emission reduction from the operation of the methane capture installation was $84.707 \%$.

\section{Conclusions}

The conclusions obtained are:

1. The results of the calculation of total emissions using the IPCC method are greatly influenced by the amount of POME produced and the method of processing the POME (whether using a methane capture installation or not).

2. By using methane capture installation, GHGs emission reduction is $84.7 \%$ (without sludge removal from the biogas reactor).

3. The actual GHGs emission reduction using methane capture installation is $70.6 \%$ with sludge removal is taken into account.

\section{References}

[1] Lokadata, "Volume produksi kelapa sawit (CPO), 2000-2018 - Lokadata." [Online]. Available: https://lokadata.beritagar.id/chart/preview/volume-produksi-kelapa-sawit-cpo-2000-2018-1550473390\#. [Accessed: 18-Aug-2019].

[2] P. Papilo, Marimin, E. Hambali, and I. S. Sitanggang, "Sustainability index assessment of palm oil-based bioenergy in Indonesia," J. Clean. Prod., vol. 196, pp. 808-820, Sep. 2018.

[3] N. H. Abdurahman and N. H. Azhari, "An integrated UMAS for POME treatment," J. Water Reuse Desalin., vol. 8, no. 1, pp. 68-75, Mar. 2018.

[4] U. Hasanudin and A. Haryanto, "PALM OIL MILL EFFLUENT RECYCLING SYSTEM FOR SUSTAINABLE PALM OIL INDUSTRIES," ASIAN J. Environ. Biotechnol., vol. 2, no. 1, pp. 52-62, Apr. 2018.

[5] E. I. Ohimain and S. C. Izah, "A review of biogas production from palm oil mill effluents using different configurations of bioreactors," Renew. Sustain. Energy Rev., vol. 70, no. December 2014, pp. 242-253, 2017.

[6] M. I. Aipassa, R. Kristiningrum, and V. Y. Tarukan, "Prospect and policy of palm oil mill effluents for future electricity in east kalimantan (utilization of pome as renewable energy)," IOP Conf. Ser. Earth Environ. Sci., vol. 144, no. 1, p. 012044, Apr. 2018.

[7] R. K. Pachauri et al., "Climate Change 2014 Synthesis Report. Contributing of Working Groups I, II and III to the Fifth Assesment Report of the Intergovernmental Panel on Climate Change," IPCC, Geneva, Switzerland, 2015.

[8] A. S. Rahayu et al., "Konversi POME Menjadi Biogas," p. 98, 2015.

[9] S. S. Harsono, P. Grundmann, and S. Soebronto, "Anaerobic treatment of palm oil mill effluents: potential contribution to net energy yield and reduction of greenhouse gas emissions from biodiesel production," $J$. Clean. Prod., vol. 64, pp. 619-627, Feb. 2014.

[10] J. Moreno, L. Martinez, L. Belalcazar, and N. Y. Rojas, "Corporate Carbon Footprint of a Palm Oil Mill," Tecciencia, vol. 13, no. 24, pp. 1-10, 2018.

[11] M. J. Chin, P. E. Poh, B. T. Tey, E. S. Chan, and K. L. Chin, "Biogas from palm oil mill effluent (POME): Opportunities and challenges from Malaysia's perspective," Renew. Sustain. Energy Rev., vol. 26, pp. 717 726, Oct. 2013.

[12] K. Rypdal et al., "Volume 1: General Guidance and Reporting," in 2006 IPCC guidelines for National Greenhouse Gas Inventories., 2006, pp. 1-12.

[13] D. R. Gomez and J. D. Watterson, "2006 IPCC Guidelines for National Greenhouse Gas Inventories: Chapter 2 Stationary Combustion,” 2006 IPCC Guidel. Natl. Greenh. Gas Invent., 2006.

[14] KLH, Pedoman Penyelenggaraan Inventarisasi Gas Rumah Kaca Nasional Buku II - Volume 1 Metodologi Penghitungan Tingkat Emisi Gas Rumah Kaca Kegiatan Pengadaan dan Penggunaan Energi Kementerian Lingkungan Hidup, vol. 1. 2012.

[15] S. E. Hosseini and M. A. Wahid, "Feasibility study of biogas production and utilization as a source of renewable energy in Malaysia," Renew. Sustain. Energy Rev., vol. 19, pp. 454-462, Mar. 2013.

[16] S. E. Hosseini and M. A. Wahid, "Development of biogas combustion in combined heat and power generation," Renew. Sustain. Energy Rev., vol. 40, pp. 868-875, Dec. 2014.

[17] R. Omar, A. Idris, R. Yunus, K. Khalid, and M. I. Aida Isma, "Characterization of empty fruit bunch for microwave-assisted pyrolysis," Fuel, vol. 90, no. 4, pp. 1536-1544, Apr. 2011.

[18] IPCC, "CHAPTER 6: Wastewater Treatment and Discharge," 2006.

[19] M. R. J. Doorn et al., "2006 IPCC Guidelines for National Greenhouse Gas Inventories: Chapter 6 Wastewater Treatment and Discharge," 2006 IPCC Guidel. Natl. Greenh. Gas Invent., pp. 1-28, 2006. 